\title{
Assessment of Sleep Habits and Quality of Sleep among Elderly Residing in Rural Areas of Patiala: A Community-Based Cross-Sectional Survey
}

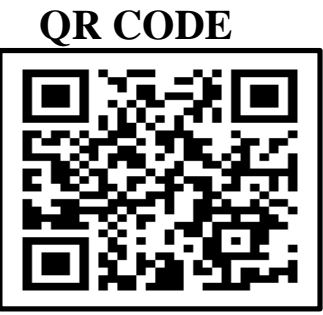

\section{YASHIKA KAUSHAL ${ }^{* 1}$, RATIBHA KAUSHAL ${ }^{2}$, ISHA SHARMA ${ }^{3}$, SHEENAB MITTAL ${ }^{4}$}

INTRODUCTION: Among the elderly, sleep problems are quite prevalent and can lead to many adverse health consequences.

AIM: To assess the quality of sleep among the elderly residing in rural population and factors related to it, and provide necessary recommendations for its prevention.

MATERIALS AND METHOD: In this cross-sectional study, elderly aged above 60 years residing in Patiala were taken and were interviewed separately using the modified version of the Pittsburgh Sleep Quality Index (PSQI), which was pre-tested and pre-validated prior to commencement of the study. Data recorded was divided into seven components and each component had an individual range of o (no difficulty) to 3 (severe difficulty) points and added to obtain a combined score of the individual with a range of o(no difficulty)-21(severe difficulty) points. Based on the combined score, elderly obtaining a total score of 5 or greater was classified as having "poor sleep quality". Statistics were applied using SPSS version 22.0, using the student's t- test, and multivariate analysis. A p value $<0.05$ was considered as significant.

RESULTS: Out of 108 elderly people, most of the participants $(62.9 \%)$ belonged to the age group of $60-75$ years, out of which the majority (65.7\%) were males. Most elderly reported having "fairly good" subjective sleep quality (53.7\%, $\mathrm{p}=0.01$ ) and was found to be significant with a global PQSI score of 7.22 \pm 4.31 . Multivariate analysis revealed that significant "poor sleep quality" was observed in elderly aged above 75 years (OR:1.25, p=0.o1) followed by elderly who were Immobilized (wheelchair/Bed ridden) (OR: 1.87, p=0.01).

CONCLUSION: Efforts should be directed towards proper education of not only the elderly, but their children as well as colleagues and guardians to improve the sleep score of the elderly population.

KEYWORDS: Sleep, Elderly, Insomnia

\section{INTRODUCTION}

In a human being's life, sleep is an unavoidable dailyrequired activity and is a highly significant factor contributing to one's overall health. ${ }^{1}$ Sleep has a positive effect on quality of life, body functions and homeostasis. ${ }^{1}$ Its deficiency can lead to the weakening of immunological functions, poor general well-being and psychiatric illnesses, especially among the elderly population. $^{2}$

Statistics from a global study featuring the sleep profiles of 48 countries revealed that not even a single country manages an average of 8 hours of sleep/night among its residents with the worst sleepers being reported from Japan, Saudi Arabia, Sweden, India and Philippines. ${ }^{3}$

Sleep deprivation is defined as getting inadequate sleep, i.e. less than 7-9 hours per day. ${ }^{4}$ Apart from sleep deprivation, Poor sleep quality includes sleep latency, restless sleep and insomnia. ${ }^{5}$ Experiments in sleep deprivation among volunteers have shown that a sleepdeprived person is incapable of sustaining normal levels of efficiency, both physically and mentally. ${ }^{6}$
Among elderly, a good quality of sleep is essential for their health, as its deprivation is linked to various diseases. As the inability to sleep can result in a negative impact leading to attention problems, delayed response time, inability to concentrate, forgetfulness, increased risk of falls, decreased performance in daily life activities and increased risk to develop depression and anxiety. ${ }^{7}$

Since the elderly are at a greater risk of the consequences of poor sleep, the present study was an attempt to assess the quality of sleep among the elderly residing in rural population in Patiala, Punjab, India and factors related to it, and provide necessary recommendations for its prevention.

\section{MATERIALS AND METHOD}

The present study was designed to be cross-sectional in nature, and was conducted among the elderly (6o years and above) residing in Patiala, Punjab, India. Post ethical clearance and obtaining all necessary approvals, the study was conducted for a period of five months i.e. from $1^{\text {st }}$ March, 2018 to $31^{\text {st }} J u l y, 2018$. Since, elderly were

(C) Yashika Kausal et al. This is an open access article distributed under the terms of the Creative Commons Attribution License CC-BY-NC 4.o, which permits unrestricted use, distribution and reproduction in any medium, provided the use is not commercial and the original author(s) and source are cited. Submitted on: 30-Sep-2021; Accepted on: 28-Oct-2021 
contacted by the researchers, the study adopted a convenience sampling. The elderly were recruited using a combination of house to house surveys, by visiting old age homes and referral by already recruited elders (Snowball sampling). All the elderly residing in one household were taken and were interviewed separately to preserve the confidentiality of data. Data was collected by primarily using the Pittsburgh Sleep Quality Index (PSQI) and adopting it as per the needs of the present study. The questionnaire was then pre-tested and prevalidated. ${ }^{8}$ The elderly were educated regarding the aims and objectives of the study and a written consent was taken from them prior to the conduct of the study.

Inclusion criteria: Elderly above 6o years; the data recorded was divided into seven components: subjective sleep quality $\left(C_{1}\right)$, sleep latency $\left(C_{2}\right)$, sleep duration $\left(C_{3}\right)$, habitual sleep efficiency $\left(\mathrm{C}_{4}\right)$, sleep disturbances $\left(\mathrm{C}_{5}\right)$, use of sleeping medications (C6) and daytime dysfunction $\left(C_{7}\right)$ over the last month. Each component has an individual range of o (no difficulty) to 3 (severe difficulty) points. Responses of all seven components were added to obtain a combined score of the individual [range of o(no difficulty)-21(severe difficulty) points]. Based on the combined score, elderly obtaining a total score of 5 or greater was classified as having a "poor sleep quality". ${ }^{8}$

Exclusion criteria: Elderly not present during the day of the study (due to any reason) and those who did not provide consent.

Data was collected and entered into Microsoft excel and descriptive statistics were applied. Inferential statistics were applied using SPSS version 22.0, 9 by using the student's t- test, and multivariate analysis. A p value < 0.05 was considered as significant.

\section{RESULTS}

Table 1 depicts that out of 108 elderly people, most of the participants $(62.9 \%)$ belonged to the age group of $60-75$ years, out of which the majority $(65.7 \%)$ were males. $81.4 \%$ of the elderly people were still married while $1.9 \%$ were never married. Unfortunately, $45.4 \%$ of the elderly reported irregular physical activity, and $8.3 \%$ were immobilized. $47.2 \%$ of the elderly were found to be smokers.

The classification of the elderly as per the components of the PSQI is depicted in table 2. Most elderly reported having "fairly good" subjective sleep quality (53.7\%, $\mathrm{p}=\mathrm{o.o1}$ ) and was found to be significant. Another significant observation was that the habitual sleep

\begin{tabular}{|c|c|}
\hline $\begin{array}{c}\text { SOCIODEMOGRAPHIC } \\
\text { VARIABLES }\end{array}$ & $\begin{array}{c}\text { FREQUENCY } \\
(\%)\end{array}$ \\
\hline AGE ( in years) & $68(62.9)$ \\
\hline $60-75$ & $40(37.1)$ \\
\hline 76 & $71(65.7)$ \\
\hline GENDER & $37(34.3)$ \\
\hline Male & $88(81.4)$ \\
Female & $18(16.7)$ \\
\hline MARITAL STATUS & $02(1.9)$ \\
\hline Still Married & \\
\hline Widowed/widower & $50(46.3)$ \\
Never Married & $49(45.4)$ \\
\hline PHYSICAL ACTIVITY & $9(8.3)$ \\
STATUS & \\
\hline Regular & \\
\hline Irregular & $51(47.2)$ \\
\hline Immobilized (wheelchair/Bed & $57(52.8)$ \\
\hline ridden) & \\
\hline SMOKING STATUS & \\
\hline Smokers & \\
\hline Non-Smokers & \\
\hline Table 1. Sociodemographic and behavioural \\
characteristics of study participants
\end{tabular}

efficiency of $>85 \%$ was observed in $80.5 \%$ of the elderly $(\mathrm{p}=0.04)$. It was also observed that $88.8 \%$ did not take any sleep medication since the last month. Significant PQSI scores of $>5$ indicating poor sleep quality was observed in $63.9 \%$ of the elderly $(\mathrm{p}=\mathrm{o.02})$.

A multivariate analysis of sleep quality (PSQI) and associated factors among the elderly (Table 3), it was observed that significant "poor sleep quality" was observed in elderly aged above 75 years (OR:1.25, $\mathrm{p}=0.01$ ) followed by elderly who were immobilized (wheelchair/bed ridden) (OR: 1.87, p=o.o1).

\section{DISCUSSION}

The present study, although descriptive in design, has provided significant insights into the sleeping habits of the $63.9 \%$ elderly of Patiala, Punjab, India. These scores are similar to the findings of Chaudhary et al. $(2020)^{2}$, but lower as compared to $72.4 \%$ reported by George et al. ${ }^{7}$ among elderly in rural Kerela India. These figures are quite alarming and demand immediate attention (Panda et al. $)^{10}$, among healthy South Indian population aged 35.1 \pm 8.7 years who reported good-quality sleep with a global PSQI score of $\leq 5$ among $93.8 \%$ of the population. Such discrepancies in the PQSI scores among adults and 


\begin{tabular}{|c|c|c|}
\hline $\begin{array}{l}\text { COMPONENTS OF } \\
\text { PSQI }\end{array}$ & FREQUENCY $(\mathbf{N}, \%)$ & $\begin{array}{c}\text { p- } \\
\text { VALUE }\end{array}$ \\
\hline \multicolumn{3}{|c|}{ Subjective Sleep Quality } \\
\hline $\begin{array}{l}\text { Very Good } \\
\text { Fairly Good } \\
\text { Fairly Bad } \\
\text { Very Bad }\end{array}$ & $\begin{array}{c}27(25) \\
58(53.7) \\
16(14.8) \\
7(6.5)\end{array}$ & $0.01^{*}$ \\
\hline \multicolumn{3}{|c|}{ Sleep Latency (in minutes) } \\
\hline $\begin{array}{c}<15 \text { minutes } \\
16-30 \text { minutes } \\
31-60 \text { minutes } \\
>60 \text { minutes } \\
\end{array}$ & $\begin{array}{l}18(16.7) \\
39(36.1) \\
22(20.4) \\
29(26.8)\end{array}$ & 0.78 \\
\hline \multicolumn{3}{|c|}{ Sleep Duration (in hours) } \\
\hline $\begin{array}{l}>7 \text { hours } \\
6-7 \text { hours } \\
5-6 \text { hours } \\
<5 \text { hours }\end{array}$ & $\begin{array}{c}28(25.9) \\
49(45.4) \\
12(11.1) \\
19(17.6)\end{array}$ & 0.065 \\
\hline \multicolumn{3}{|c|}{ Habitual Sleep Efficiency } \\
\hline $\begin{array}{l}>85 \% \\
75-84 \% \\
65-74 \% \\
<65 \% \\
\end{array}$ & $\begin{array}{c}87(80.5) \\
14(12.9) \\
6(5.5) \\
1(1.1)\end{array}$ & $0.04^{*}$ \\
\hline \multicolumn{3}{|c|}{ Use of Sleep Medication } \\
\hline $\begin{array}{c}\text { Not during the past } \\
\text { month } \\
\text { Less than once a } \\
\text { week } \\
\text { Once or twice a week } \\
\text { Three or more time a } \\
\text { week } \\
\end{array}$ & $\begin{array}{l}96(88.8) \\
3(2.8) \\
6(5.6) \\
3(2.8)\end{array}$ & 0.89 \\
\hline \multicolumn{3}{|c|}{ Day Time Dysfunction } \\
\hline $\begin{array}{l}\text { Not difficult } \\
\text { Little difficult } \\
\text { Difficult } \\
\text { Very difficult }\end{array}$ & $\begin{array}{c}69(71.8) \\
15(15.6) \\
7(7.2) \\
5(5.2)\end{array}$ & 0.06 \\
\hline \multicolumn{3}{|c|}{ Sleep Disturbances } \\
\hline $\begin{array}{c}\text { Not in last month } \\
\text { Once in a week } \\
\text { 1-2 times a week } \\
\text { More than thrice a } \\
\text { week }\end{array}$ & $\begin{array}{c}2(2) \\
81(75.0) \\
13(12.1) \\
14(12.9)\end{array}$ & 0.77 \\
\hline \multicolumn{3}{|c|}{ Total PSQI score of Study Participants } \\
\hline $\begin{array}{l}\text { Less than } 5 \\
\text { More than } 5\end{array}$ & \begin{tabular}{|c|c|} 
& GLOBAL \\
& PQSI \\
& SCORE \\
& $(\mathrm{MEAN} \pm$ \\
& SD) \\
69 & $7.22 \pm 4.31$ \\
$(63.9)$ &
\end{tabular} & $0.02^{*}$ \\
\hline
\end{tabular}

Table 2. Distribution of respondents according to components of Pittsburgh Sleep Quality Index (PSQI)

elderly focus on the need for promoting good sleep habits among the elderly through proper screening for

\begin{tabular}{|c|c|c|}
\hline ASSOCIATED FACTORS & OR $(95 \% \mathrm{CI})$ & $\begin{array}{l}\text { P- } \\
\text { VALUE }\end{array}$ \\
\hline \multicolumn{3}{|l|}{ Age (in years) } \\
\hline $60-75$ & $1.32(0.74-12.25)$ & 0.90 \\
\hline$>76$ & $1.35(0.55-15.58)$ & $0.01^{*}$ \\
\hline Widow & $0.22(0.14-1.95)$ & 0.55 \\
\hline $\begin{array}{l}\text { Immobilized } \\
\text { (wheelchair/Bed ridden) }\end{array}$ & $1.87(0.56-20.68)$ & $0.01^{*}$ \\
\hline Smokers & $1.88(1.47-21.75)$ & 0.06 \\
\hline
\end{tabular}

Table 3. Multivariate analysis of sleep quality (PSQI) and associated factors

potential factors disturbing their sleep patterns. The global PQSI score of the elderly in the present study was found to be 7.22 \pm 4.31 , which is lower as compared to George et al. (8.04 \pm 4.59$)^{7}$ and lower in comparison to Das et al. ${ }^{11}$ (Higher IQR of GPQSI scores in population aged $>70$ years). As reported by Farazdaq et al., ${ }^{12}$ a few factors associated with an increased risk of poor sleep quality among elderly included aging, divorce, being widowed, caffeine consumption, cigarette smoking 2 hours before bedtime coupled with co-morbidities such as GERD and depression to name a few.

As per results of $\mathrm{Wu}$ et al. ${ }^{13}$ higher level of physical activity was associated with better sleep quality among elderly population in Taipei while independently considering physical influence on sleep. As per results of the present study, $45.4 \%$ of the elderly had irregular physical activity while $8.3 \%$ were immobilized and hence, could not do any physical activity. This could be the reason for such poor sleep scores in the elderly studied in the present study. In addition, Razali et al. ${ }^{14}$ reported that sleep quality was associated with age the same can be seen with the results of the present study.

The limitations of the study include social desirability bias by the respondents or recall bias(in some instances). In addition, data as coded and the interviewers were duly standardized to eliminate interviewer's bias. Due to such measures, the authors conclude that the results of the present study can be generalized for the Indian population and can be used for comparison between global elderly population.

\section{CONCLUSION}

Based on the results of the present study, the sleep scores of the elderly were high and efforts should be directed towards proper education of not only the elderly, but their children as well as colleagues and guardians through proper community education programmes so 
that efforts could be directed towards improving the sleep score of the elderly population.

\section{DISCUSSION}

1. Sexton-Radek K, Pichler-Mowry R. Daily activities and sleep quality in young adults. Percept Mot Skills. 2011;112:426-8.

https://doi.org/10.2466/o6.13.PMS.112.2.426-428.

2. Chaudary J, Jain B, Bhadoria AS, Kishore S, Aggarwal P. Assessment of Sleep Habits and Quality of Sleep among Elderly Residing In Rural Area of Dehradun: A Community-Based Cross-Sectional Survey. Natl J Community Med. 2020;11(2):98-102

3. Dreams UK. This Data Shows A Shocking Worldwide Lack of Sleep.

Available from https://www.dreams.co.uk/sleepmattersclub/data-shows-a-shocking-worldwide-lack-ofsleep/[Last Accessed on April 10 ${ }^{\text {th }}$, 2021]

4. Kumari R, Jain K, Nath B. Sleep quality assessment among college students using Pittsburgh Sleep

Quality Index in a municipal corporation area of Uttarakhand, India. Ceylon Medical Journal 2020; 65: 8694. http://doi.org/10.4038/cmj.v65i4.9279

5. Rodéhn M. The importance of sleep. Nursing Standard (Royal College of Nursing (Great Britain): 1987). 1999; 13(24): 44-7.

6. Oswald I. Sleep. London: Penguin Books; 1980.

7. George S, Paul G, Paul N. Study on sleep quality and associated psychosocial factors among elderly in a rural population of Kerala, India. Int J Community Med Public Health. 2018;5:526-31.
8. Buysse DJ, Reynolds CF $3^{\text {rd }}$, Monk TH, Berman SR, Kupfer DJ. The Pittsburgh Sleep Quality Index: a new instrument for psychiatric practice and research. Psychiatry Res. 1989 May;28(2):193-213. https://doi.org/10.1016/0165-1781(89)90047-4.

9. IBM Corp. Released 2013. IBM SPSS Statistics for Windows, Version 22.0. Armonk, NY: IBM Corp.

10. Panda S, Taly AB, Sinha S, Gururaj G, Girish N, Nagaraja D. Sleep-related disorders among a healthy population in South India. Neurol India 2012;60:68-74. https://doi.org/10.4103/o028-3886.93601

11. Das S, Roy RN, Das DK, Chakraborty A, Mondal R. Sleep Quality and its various correlates: A communitybased study among geriatric population in a community development block of Purba Bardhaman district, West Bengal. J Family Med Prim Care. 2020;9:1510-6. https://doi.org/10.4103/jfmpc.jfmpc_1021_19

12. Farazdaq H, Andrades M, Nanji K. Insomnia and its correlates among elderly patients presenting to family medicine clinics at an academic centre. Malays Fam Physician. 2018;13:12-9.

13. Wu CY, Su TP, Fang CL, Chang MY. Sleep quality among community-dwelling elderly people and its demographic, mental, and physical correlates. J Chinese Med Assoc. 2012;75:75-80. https://doi.org/10.1016/j.jcma.2011

14. Razali R, Ariffin J, Aziz A. Sleep quality and psychosocial correlates among elderly attendees of an urban primary care centre in Malaysia. Neurology Asia 2016;21:265-73.

\section{AUTHOR AFFILIATIONS: ( ${ }^{*}$ Corresponding Author)}

1. MBBS, Presently Clinical Observer, International Medical Graduate, Unit Number 322, Building Number 8o68, 120 A Street, Surrey, British

Columbia, Canada, Postal Code- $\mathrm{V}_{3} \mathrm{~W}_{3} \mathrm{P}_{3}$

2. MBBS, International Medical Graduate, British Columbia, Canada

3. Private Practitioner, Patiala, Punjab, India

4. Third Year Junior Resident, Department of Pathology, Govt. Medical College and Rajendra Hospital, Patiala, Punjab, India 